\title{
FAKTOR - FAKTOR YANG BERPENGARUH DALAM PROSES REKLAMASI UNTUK MENGANTISIPASI BENCANA DI LINGKUNGAN PANTAI
}

\author{
FACTORS AFFECTING RECLAMATION PROCESS \\ TO ANTICIPATE DISASTER IN THE COASTAL ENVIRONMENT
}

\author{
CB Herman Edyanto
}

\begin{abstract}
ABSTRAK: Reklamasi sering diterjemahkan sebagai upaya proses pembuatan daratan baru dari dasar laut atau dasar sungai. Tanah yang direklamasi disebut tanah reklamasi atau landfill. Pada beberapa negara, hal ini telah lama dilakukan, seperti Singapura, Hongkong, Jepang dan Belanda. Kebutuhan lahan, merupakan permasalahan yang pokok pada saat meningkatnya kegiatan ekonomi dan sosial bagi masyarakat serta tuntutan perkembangan fisik kota yang naik secara signifikan dan tidak diimbangi dengan ketersediaan lahan itu sendiri. Laut menjadi salah satu solusi yang menawarkan sedikit permasalahan namun banyak memberikan kemudahan, walau untuk merealisasikan rencana itu membutuhkan biaya yang tidak sedikit. Kini tujuan reklamasi berkembang ke arah upaya pengurangan risiko bencana, setelah berbagai daerah mengalami bencana seperti banjir dan rob. Reklamasi masih menjadi perdebatan berbagai kalangan, namun visi ke depan para pengambil keputusan menggambarkan sinkronisasi antara modernisasi perkembangan perkotaan dengan upaya pengurangan bencana. Untuk itu dibutuhkan analisis faktor faktor yang berpengaruh pada proses perencanaannya.
\end{abstract}

Kata kunci: reklamasi, risiko bencana, modernisasi kota, analisis faktor, gempabumi

ABSTRACT: Reclamation is often translated as an effort of making a new land on the sea floor or riverbed. Reclaimed land is called the land reclamation or landfill. In several countries, land reclamation has been done for a long time ago, such as in Singapore, Hong Kong, Japan and the Netherlands. The need of land is the fundamental problem, in particular when increasing economic and social activities and the demands of the physical development of the city which rose significantly was not provided by the availability of land itself. Sea area for reclamation is one solution that offers a little problem but gives many conveniences, although to realize the reclamation requires high cost. Nowadays the purpose of reclamation evolving towards the disaster risk reduction efforts, aftermany regions experienced disasters such as floods and rob. Reclamation is still being debated by various stakeholders, but the vision of the decision makers for the future describes the synchronization between the modernization of urban development with disaster reduction efforts. For that purposes it requires the analysis of the factors which will influence the planning process.

Keywords: reclamation, disaster risk, city modernisation, factor analyses. 


\section{PENDAHULUAN}

Menurut Undang Undang No. 27 Tahun 2007, reklamasi didefinisikan sebagai kegiatan yang dilakukan oleh orang dalam rangka meningkatkan manfaat sumber daya lahan ditinjau dari sudut lingkungan dan sosial ekonomi dengan cara pengurugan, pengeringan lahan atau drainase. Reklamasi dapat juga didefinisikan sebagai aktivitas penimbunan suatu areal dalam skala relatif luas hingga sangat luas di daratan maupun di areal perairan untuk suatu keperluan rencana tertentu.

Dalam definisi di atas terdapat syarat dan ketentuan bahwa kawasan yang diperbaiki tersebut adalah berair. Dalam teori perencanaan kota, reklamasi pantai merupakan salah satu langkah pemekaran kota. Reklamasi diamalkan oleh negara atau kota-kota besar yang laju pertumbuhan dan kebutuhan lahannya meningkat demikian pesat tetapi mengalami kendala dengan semakin menyempitnya lahan daratan (keterbatasan lahan). Kawasan reklamasi pantai merupakan kawasan hasil perluasan daerah pesisir pantai melalui rekayasa teknis untuk pengembangan kawasan baru. Kawasan reklamasi pantai termasuk dalam kategori kawasan yang terletak di tepi pantai, dimana pertumbuhan dan perkembangannya baik secara sosial, ekonomi, dan fisik sangat dipengaruhi oleh badan air laut (http://www.penataanruang. com/reklamasi-pantai. html). Dengan kondisi tersebut, pemekaran kota ke arah daratan sudah tidak memungkinkan lagi, sehingga diperlukan daratan baru (https:// outsidergianyar.wordpress.com/pengertianreklamasi/). Tujuan reklamasi adalah menjadikan kawasan yang tidak berguna atau tidak bermanfaat menjadi kawasan yang mempunyai manfaat. Kawasan yang sudah direklamasi tersebut biasanya dimanfaatkan

${ }_{1}$ PTRRB - BPPT, Jl. M. H. Thamrin No.8, Jakarta 10340

email: edyanto@yahoo.com untuk kawasan pertanian, pemukiman, perindustrian, pertokoan atau bisnis dan objek wisata. Pekerjaan reklamasi juga bertujuan untuk memacu pembangunan sarana dan prasarana pendukung lainnya (http:// materiperkapalan.blogspot.com/2014/11/ pengertian-dan-tujuan-reklamasi-untuk.html). Prinsip dalam upaya reklamasi adalah:

- Kebutuhan dalam pengembangan budi daya untuk suatu kawasan yang berada pada sisi daratan.

- Dapat merupakan kawasan perkotaan yang padat maka membutuhkan pengembangan wilayah untuk mengakomodasikan kebutuhan.

- Pada dasarnya kegiatan reklamasi pantai tidak dianjurkan namun dapat dilakukan dengan memperhatikan ketentuan berikut:

- Merupakan kebutuhan pengembangan kawasan budi daya yang telah ada di sisi daratan.

- Merupakan bagian wilayah dari kawasan perkotaan yang cukup padat dan membutuhkan pengembangan wilayah daratan untuk mengakomodasikan kebutuhan yang ada.

- Berada di luar kawasan hutan bakau yang merupakan bagian dari kawasan lindung atau taman nasional, cagar alam dan suaka margasatwa.

- Bukan merupakan kawasan yang berbatasan atau dijadikan acuan batas wilayah dengan daerah atau negara lain. Terhadap kawasan reklamasi pantai yang sudah memenuhi ketentuandiatas(http://www.academia. edu/4293653/reklamasi_pantai_dan_ dampaknya_terhadap_wilayah _pesisir).

Reklamasi dikategorikan berdasarkan luasannya, yaitu Reklamasi Besar memiliki luasan lebih dari 500 hektar, dengan pemanfaatan yang sangat bervariasi. Reklamasi Sedang memiliki luasan 100 hingga 500 hektar, dengan lingkup pemanfaatannya yang tidak begitu banyak (antara 3 hingga 6 jenis pemanfaatan). Reklamasi Kecil memiliki luasan 
dibawah 100 hektar, dengan pemanfaatan yang sangat terbatas. Dalam melaksanakan reklamasi terdapat prosedur yang diawali dari tahap perencanaan, pelaksanaan dan pembangunan serta pemanfaatannya baik di atas maupun di bawah lahan hasil reklamasi dan pengendalian ruangnya.

\subsection{Dampak Positif}

Kebutuhan dan manfaat reklamasi dapat dilihat dari berbagai aspek tata guna lahan, aspek pengelolaan pantai dan ekonomi. Kebutuhan lahan yang berkaitan dengan kegiatan ekonomi dan transportasi laut menuntut adanya pelabuhan, industri, wisata atau pemukiman, yang harus dipenuhi oleh sebuah kota pantai. Pada kota pelabuhan yang memiliki perairan pantainya dangkal,maka lahan pantainya wajib untuk direklamasi agar bisa dimanfaatkan bagi kepentingan trasportasi laut. Demikian pula untuk kebutuhan pemukiman. Dengan fakta semakin mahalnya harga tanah daratan dan menipisnya daya dukung lingkungan di darat maka reklamasi menjadi pilihan bagi pemerintah atau kota metropolitan dalam memperluas lahannya melalui reklamasi.

Keuntungan lain adalah dapat berfungsi untuk mengurangi kepadatan pemukiman yang menumpuk di kota melalui relokasi permukiman ke lokasi reklamasi, sehingga terbebas dari penggusuran. Disisi aspek lingkungan, pada kasus tertentu, terjadi perubahan pola arus air laut mengalami abrasi, akresi sehingga memerlukan pembuatan pemecah ombak (groin) atau dinding laut. Reklamasi perlu dilakukan di wilayah pantai seperti ini, sehingga terbentuk konfigurasi pantai yang terkena abrasi seperti bentuk semula.

Pengurugan tanah sebagai bagian utama dalam pelaksanaan reklamasi memiliki keuntungan dalam upaya penambahan daratan buatan, sehingga dapat dimanfaatkan untuk bermacam macam kebutuhan. Kawasan yang merupakan lokasi reklamasi terlindungi dari erosi karena konstruksi pengaman sudah disiapkan sekuat mungkin untuk dapat menahan gempuran ombak.
Pada kasus tertentu daerah yang memiliki ketinggian di bawah permukaan laut bisa aman terhadap banjir apabila dibuat tembok penahan air laut di sepanjang pantai melalui reklamasi lahan pantai, contohnya seperti Amsterdam. Keuntungan lainnya adalah penataan lingkungan pantai dengan tata letak penghijauan pantai yang serasi, memberikan nilai positif dalam pengembangan rekreasi lokal dan daya tarik masyarakat kota pantai.

\subsection{Dampak Negatif}

Dampak negatif memberikan permasalahan fisik sosial dan ekonomi bagi masyarakat pantai. Terganggunya aliran air ke tambak dapat berakibat kematian ikan yang sering diartikan sebagai berkurangnya sumber pendapatan nelayan dan membunuh biota lainnya di sekitar wilayah tersebut. Namun yang paling merugikan adalah hilangnya tempat berpijah bagi ikan-ikan tertentu di kawasan tersebut terutama bila proses reklamasi mengurug sebagian atau seluruh hutan bakau. (https://beritasepuluh.com/2016/04/18/opinipakar-tentang-reklamasi-teluk-jakarta/).

Pada dasarnya tanah reklamasi kurang stabil dan rawan terhadap proses likuifaksi selama gempa bumi dan dapat mengakibatkan kerusakan bangunan dan infrastruktur. Reklamasi yang tidak sempurna dapat berakibat amblesan tanah (land subsidence) terutama pada prosesi pemadatan tanah pada lahan yang diisi. Proses reklamasi yang tidak sempurna dapat berakibat pada terjadinya proses intrusi air laut, sehingga pada beberapa lokasi areal pertanian akan terjadi kerusakan tanaman karena tidak dapat digunakan untuk bercocok tanam. Reklamasi pantai yang semula merupakan ruang publik bagi masyarakat akan hilang atau berkurang karena penguasaan lahan bagi kepentingan yang bersifat pribadi.

Reklamasi mampu untuk merubah garis pantai karena adanya perubahan arus laut yang dibelokkan oleh bentukan lahan reklamasi. Sistem hidrologi gelombang air laut yang menyinggung garis pantai akan berubah 
arah arusnya. Hal ini akan mengakibatkan daerah di luar reklamasi akan mendapat limpahan air yang banyak sehingga kawasan ini akan terjadi abrasi dan tergerus dan dapat terjadi banjir di kawasan ini.

Reklamasi berpengaruh pada kondisi lingkungan ekosistem. Berubahnya ekosistem perairan yang mengakibatkan berubahnya keseimbangan ekosistem lingkungan yang berakibat pada kerusakan pantai. Reklamasi juga mampu menciptakan banjir pada titik terendah di kawasan pantai karena dapat mengubah bentang alam dan perubahan aliran air di kawasan terendah tersebut sehingga mengakibatan banjir rob.

\section{PERMASALAHAN}

Munculnya kawasan baru sebagai hasil dari reklamasi pantai perlu disinkronkan dan diintegrasikan dalam Rencana Tata Ruang Wilayah (RTRW). Permasalahan reklamasi berkembang, tidak saja berkaitan dengan aspek fisik, namun juga mengarah kepada aspek ekonomi dan sosial budaya dan lingkungan. Perubahan fisik karena reklamasi akan merubah tingkat kestabilan ekologi. Keseimbangan lingkungan alamiah yang selalu berada dalam keadaan seimbang dan dinamis kini berubah. Demikian pula adanya perubahan fisik pantai mengakibatkan terputusnya mata rantai makanan anak anak ikan, timbulnya perubahan suhu, hilangnya tempat berlindung dan mengakibatkan punahnya mahluk air ini. Masalah ini terus bergulir karena nelayan kekurangan jumlah ikan yang dapat ditangkap sehingga pendapatannyapun berkurang. Reklamasi yang berupa pengurugan tanah, membutuhkan material pengurugan yang tidak sedikit. Seringkali dijumpai lahan di pulau pulau kecil sekitarnya tereksploitasi sebagai bahan material reklamasi. Perubahan garis pantai sebagai akibat dari perubahan hidrodinamika. Perubahan ini terjadi karena kawasan reklamasi akan merubah pola arus laut yang mampu untuk menggerus garis pantai pada kawasan lain.

\section{METODE}

Metode yang digunakan untuk studi ini adalah dengan menggunakan metode kualitatif, yakni dengan melakukan studi pustaka dari hasil studi terdahulu dan mencermati undang undang dan peraturan menjadi landasan hukum dalam perencanaan ruang yang berkaitan dengan lahan reklamasi. Dengan prinsip bahwa kegiatan reklamasi pantai merupakan kebutuhan pengembangan kawasan budidaya yang telah ada disisi daratan dan merupakan bagian dari wilayah perkotaan yang terbangun secara optimal, padat dan membutuhkan lahan tambahan pengembangan wilayah daratan yang berfungsi untuk menampung tuntutan kebutuhan yang ada, maka perencanaan lahan reklamasi harus terintegrasi dengan RTRW provinsi, atau RTRW kota atau RTRW kabupaten dan Rencana Detil Tata Ruang Kawasan Reklamasi. Analisis dalam pembahasan ini akan berdasar pada proses penataan ruang dimana segi perencanaan, pemanfaatan dan pengendalian ruangnya menjadi tahapan yang utama. Analisis mengenai struktur dan pola ruang yang terlingkup dalam tahap perencanaan menjadi hal penting dalam analisis ini.

\section{HASIL DAN PEMBAHASAN}

\subsection{Landasan Hukum Pengelolaan Lahan Reklamasi}

Proses reklamasi membutuhkan waktu yang panjang yang membutuhkan sisi legalitas dalam pelaksanaannya. Beberapa peraturan penataan ruang mendudukan beberapa Undang Undang sebagai landasan aspek legaitasnya seperti Undang Undang No. 32 Tahun 1990 tentang Pegelolaan Kawasan Lindung yang akan menjadi arahan dalam klasifikasi kawasan lindung, pemanfaatan ruangnya, dan juga di kawasan budidaya. Undang Undang No. 27 Tahun 2007 tentang Pengelolaan Pesisir dan Pulau Pulau Kecil, 
Undang Undang No. 26 tahun 2007 tentang Penataan Ruang yang bersifat memayungi seluruh kegiatan penyusunan berbagai dokumentasi di kawasan ini. Undang Undang No. 26 tahun 2007 ini, didukung oleh beberapa peraturan lainnya seperti PP No. 69 tahun 1996 tentang Pelaksanaan Hak dan Kewajiban serta Bentuk dan Tata Cara Peran Serta Masyarakat dalam penataan Ruang dan Peraturan Pemerintah lainnya. Pada dasarnya semua peraturan penataan ruang ini merupakan upaya untuk menuju pada penetapan acuan pemerintah daerah mengenai bentuk tipologi zona kawasan reklamasi pantai, pemanfaatan ruang kawasan reklamasi, dan penentuan struktur dan pola ruang kawasan reklamasi pantai. Untuk mewujudkan rencana tindak dari Undang Undang No. 24 tahun 2007 Tentang Penanggulangan Bencana, perencanaan kota pantai dilaksanakan dalam koridor sistem proses penataan ruang, yaitu melakukan perencanaan tata ruang, pemanfaatan ruang dan pengendalian pemanfaatan ruang.

\subsection{Faktor Yang Berpengaruh Dalam Proses Perencanaan Kawasan Reklamasi}

Dalam proses rencana penataan ruang kawasan reklamasi, beberapa faktor yang dipertimbangkan :

- Faktor Kesiapan Kawasan Reklamasi.

Faktor kesiapan menjadi hal yang utama sebelum seluruh kegiatan di kawasan tersebut berjalan, Dalam perencanaan kawasan reklamasi perlu untuk mempertimbangkan beberapa hal seperti perhitungan terhadap aspek perubahan garis pantai (hidrodinamika pantai), aspek struktur bangunan pantai dan persyaratannya, metoda reklamasi yang digunakan, bahan pengurugan yang dipakai, lokasi pengambilan bahan urugan dan standarnya. Secara teknis untuk hal-hal tertentu dibutuhkan spesifikasi teknis reklamasi.

- Faktor Implementasi Proses Reklamasi. Dalam proses reklamasi akan terkait berbagai persyaratan yang harus dipertimbangkan terutama yang terkait dengan bangunan laut, proses pembebanan sementara, pengurugan dan pemadatan, geotextile, dan vertical drain. Pengambilan bahan bahan urugan dipertimbangkan amterial yang baik dan mampu untuk menahan beban diatasnya. Demikian pula tanah urugan ditekan (soil pressed) sedemikian rupa sehingga tidak terjadi amblesan dikemudian hari. Pengambilan material urugan ini dilakukan pada kawasan perbukitan yang tidak berpenghuni setelah mendapat izin dari pemerintah daerah. Pada beberapa lokasi, pengambilan material urugan juga dilakukan di pulau pulau kecil sekitarnya yang tidak berpenghuni, namun hal ini tidak disarankan karena akan mengganggu ekologi lingkungan. Hal yang sering dilakukan juga adalah pengambilan material pengurugan dari dasar laut. Pekerjaan ini dilakukan dengan menggunakan kapal pengeruk dan penghisap pasir di dasar laut dan dapat merusak lingkungan dasar laut.

- Faktor Paska Reklamasi.

Faktor ini akan berkaitan dengan berbagai persyaratan teknis yang dibutuhkan seperti persyaratan konstruksi baja dan beton, bangunan lainnya. Persyaratan ini akan bervariasi tergantung dari fungsi kawasan reklamasi dan tingkat pemanfaatannya. Fungsi kawasan reklamasi dapat berupa kawasan perumahan atau permukiman, kawasan industri, kawasan pariwisata, kawasan perdagangan dan jasa, kawasan pelabuhan, kawasan pelabuhan udara, kawasan ruang terbuka dan sebagainya. Semakin intensif pemanfaatan lahannya, semakin bervariasi persyaratan teknis pembangunannya.

- Faktor Pengendalian Dampak Negatif Lingkungan.

Proses reklamasi merupakan campur tangan manusia melawan alam di kawasan pantai, seperti adanya limpasan 
air sebagai dampak dari reklamasi yang mengakibatkan banjir di kawasan lain. Hal lain yang dipertimbangkan adalah ketersediaan air bersih dan energi. Tidak semua lokasi di kawasan reklamasi akan diperoleh air bersih mengingat kawasan itu sendiri merupakan areal yang digenangi oleh air asin, sehingga masih akan membebani ketersediaan air di daratan.

Sebagai kawasan yang baru dibuka, maka paparan pemanfaatan lahan akan mencerminkan besarnya pergerakan yang akan terjadi, maka aspek lain yang perlu untuk dipertimbangkan adalah transportasi. Transportasi di kawasan ini akan meningkat, terutama pada pusat kegiatan dan daerah reklamasi. Kondisi ini perlu diantisipasi mengingat cepatnya pola pembangunan fisik di lokasi tersebut yang perlu diimbangi dengan pola transportasi yang memadai. Sistem transportasi yang terintegrasi dapat menjadi solusi yang baik, misalnya penggunaan jalan bawah tanah (subway),rel kereta dan bus.

- Sesuai dengan rencana pendahuluan bahwa reklamasi harus terintegrasl dengan rencana kota atau kabupaten, maka lahan hasil reklamasi akan dimanfaatkan sebagai bagiankomponendariperencanaankotaatau kabupaten yang belum tersalurkan dalam Rencana Tata Ruang Kota atau Kabupaten. Oleh karena itu dalam pelaksanaan pembangunannya perlu sistem kontrol yang ketat sehingga terhindar dari kesalahan dalam penataan ruang, seperti terjadinya penyebaran kawasan kumuh dan sebagainya.

Hal penting lainnya yang berkaitan dengan rencana pembangunan fisik yang cukup berpengaruh adalah pentingnya investigasi struktur lapisan tanah yang menjadi syarat utama untuk mendapatkan ketahanan struktur. Perhitungan untuk kekuatan reklamasi terhadap abrasi maupun struktur bangunan fisik diatasnya juga perlu diperhitungkan.

Dalam rangka menata pembangunan kawasan reklamasi pantai diperlukan suatu pedoman teknis yang operasional bagi pemerintah, masyarakat, dan swasta dalam penyelenggaraan penataan ruang di kawasan reklamasi pantai (http://www.penataanruang.com/reklamasi-pantai. $\mathrm{html}$ ). Dalam Undang-undang No. 27 tahun 2007 pada pasal 34 dijelaskan bahwa kegiatan semacam reklamasi hanya dapat dilaksanakan jika manfaat sosial dan ekonomi yang diperoleh lebih besar dari biaya sosial dan biaya ekonominya. Namun demikian, pelaksanaan reklamasi juga wajib menjaga dan memperhatikan beberapa hal seperti:

a) Keberlanjutan kehidupan dan penghidupan Masyarakat.

b) Keseimbangan antara kepentingan pemanfaatan dan pelestarian lingkungan pesisir.

c) Persyaratan teknis pengambilan, pengerukan dan penimbunan material (http://www.academia. edu/4293653/ reklamasai_pantai_dan_dampaknya _terhadap_wilayah_pesisir).

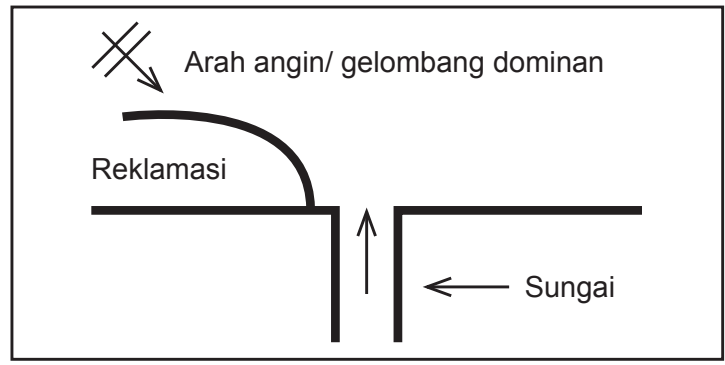

Gambar 1. Contoh reklamasi pantai yang benar.

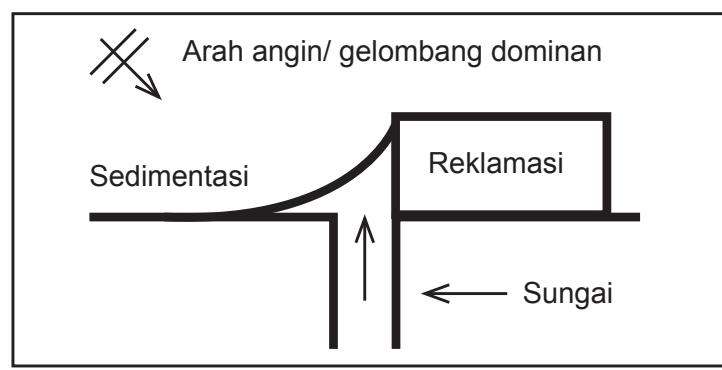

Gambar 2. Contoh reklamasi pantai yang salah.

Sumber: Modul Terapan Pedoman Perencanaan Tata Ruang Kawasan Reklamasi Pantai Peraturan Menteri Pekerjaan Umum No.40/PR/M/2007. 


\subsection{Reklamasi Dan Penataan Ruang}

Penambahan lahan dalam bentuk reklamasi, tidak terlepas dari perencanaan kawasan di sekitarnya, baik dalam bentuk tata ruang kota atau kabupaten maupun dalam bentuk tata ruang wilayah. Kawasan reklamasi adalah bagian dari sistem perencanaan yang terpadu secara utuh. Dengan demikian kawasan reklamasi akan mendapatkan perlakuan perencanaan, pemanfaatan dan pengendalian ruang sebagaimana yang telah berjalan pada kawasan rawan bencana lainnya. Dalam kawasan reklamasi perlu disusun perencanaan struktur ruang dan pola ruangnya yang terintegrasi dengan perencanaan di atasnya dengan ketentuan arahan peruntukan fungsinya. Dengan demikian dapat disusun Rencana Detail Tata Ruang (RDTR) kawasan reklamasinya, serta Rencana Struktur Ruang, Rencana Pola Ruang dan intensitas Pemanfaatan Ruangnya. Arahan dalam struktur ruang akan mencakup infrastruktur, drainase, air bersih, dan sanitasi. Demikian pula hal yang mencakup utilitas, seperti jaringan telpon, listrik dan gas. Aksesibilitas, sarana perkotaan, transportasi dan ruang parkir, amenitas. Arahan untuk pola ruang akan mencakup kawasan permukiman, perdagangan dan jasa pendidikan, pelabuhan ruang terbuka, pelabuhan dan bandar udara.

Sebagai kawasan yang baru, maka pengembangan kawasan reklamasi membutuhkan beberapa pedoman, seperti Pedoman Perencanaan Tata Ruang Kawasan Reklamasi Pantai, Pedoman Teknis Analisis Aspek Fisik dan Lingkungan, Ekonomi, Budaya, dan Sosial dalam perencanaan tata ruangnya. Disamping itu dibutuhkan pula Pedoman Kriteria Teknis Kawasan Budidaya dan Pedoman Penataan Ruang Kawasan Lainnya (Departemen Pekerjaan Umum, Direktorat Jenderal Penataan Ruang, 2008).

\subsubsection{Tahapan Proses Perencanaan Kawasan Reklamasi}

Dalam evaluasi penataan

ruang, terdapat beberapa tahapan yaitu proses perencanaan, pemanfaatan dan pengendalian. Pada tahap perencanaan kriteria kawasan reklamasi yang dibangun adalah optimasi pencapaian sasaran evaluasi untuk pelaksanaan perencanaan tata ruang kawasan reklamasi berbasis pengurangan risiko bencana. Indikatornya adalah:

- Adanya integrasi perencanaan tata ruang dengan kawasan utama (seperti rencana induk kota atau kabupaten).

- Adanya rencana lokasi struktur ruang kota yang berorientasi pada pengurangan risiko bencana di kawasan reklamasi. Acuannya adalah adanya:

1. Ketersediaan lahan dan alokasi kegiatan seperti pusat dan sub pusat permukiman pada kawasan reklamasi.

2. Kesiapan rencana pola tata letak permukiman.

3. Kesiapan rencana sistem pertahanan pantai yang memadai.

4. Terpolanya jejaring jalur jalan untuk aksesibilitas dengan kawasan daratan.

5. Rencana penentuan lokasi bangunan yang berfungsi sebagai pelayanan publik yang penting (Dooley, 1996), seperti stasiun pemadam kebakaran, kantor polisi, kantor militer dan keamanan masyarakat, puskesmas dan rumah sakit, kantor pelayanan masyarakat , kantor instansi pemerintah di kawasan reklamasi.

6. Rencana lokasi pembangunan hunian khusus seperti penjara, universitas, sekolah, rumah jompo, pusat generator dan gardu listrik.

7. Rencana pembangunan fasilitas pelayanan penting yang berbahaya seperti gudang kimia, penyimpanan bahan peledak atau peluru, gudang bahan bakar, gudang bahan baku dan persenjataan nuklir, SPBU berada di kawasan reklamasi. 
Komponen pendukungnya adalah:

- Ketersediaan dan kelengkapan data atau informasi seperti rencana pemukiman seperti jumlah rumah yang akan dibangun, kepadatan bangunan.

- Ketersediaan data dan informasi mengenai rencana jumlah penduduk, kepadatannya, dan distribusi penduduk.

- Ketersediaan data rencana infrastruktur yang akan dibangun (jalan, listrik, jalur gas, jalur telepon, jalur air minum).

- Ketersediaan peta tentatif (tata guna lahan, kontur, morfologi, dan sebagainya) kawasan reklamasi.

Petunjuk (indikator) lainnya untuk kriteria evaluasi tata ruang kota pantai ini adalah adanya Rencana Pola Ruang yang mampu mengurangi kerentanan terhadap bencana di pantai, seperti abrasi. Tolok ukurnya adalah:

- Adanya rencana pemanfaatan lahan di kawasan non budidaya untuk bangunan fisik pertahanan pantai, seperti pemecah gelombang buatan (seawall), tanggul (dike), bukit pasir (sand dunes). Rencana ini akan terintegrasi dengan pemanfaatan lahan lainnya, seperti eksistensi hutan bakau dan karang laut (mangrove forest and coral reef) dan zona penyangga yang difungsikan sebagai pelindung terhadap limpasan gelombang laut.

- Ketersediaan rencana peruntukan yang berfungsi sebagai ruang terbuka sebagai ruang evakuasi dalam bentuk shelter atau bangunan bertingkat dengan lantai bawah terbuka di zona yang dibangun untuk pemukiman, namun dengan tingkat kepadatan penduduk yang rendah (Risk Sustainability Zones) dengan ketinggian bangunan yang relatif lebih tinggi dari sekitarnya.

- Adanya rencana struktur bangunan yang kokoh menjadi syarat penting karena tanah reklamasi merupakan tanah yang kurang stabil, yang lebih diarahkan pada fasilitas publik, sedangkan struktur bangunan biasa diarahkan pada fasilitas yang kurang fungsional.

- Adanya indikasi program rencana penerapan standar perlindungan kawasan sempadan pantai dan sungai (100 $\mathrm{m}$ dari bibir pantai atau sungai).

\subsubsection{Tahapan Proses Pemanfaatan Kawasan Reklamasi}

Pemanfaatan ruang kawasan reklamasi secara implisit memiliki arti optimasi pemanfaatan lahan serta perlindungan secara menyeluruh terhadap penduduk dan fasilitas di kawasan reklamasi. Evaluasi terhadap rencana tata ruang kota yang ada dan yang perlu diintegrasikan dengan tata guna lahan kawasan reklamasi dan berupaya untuk mengurangi dampak negatif yang mungkin akan terjadi. Petunjuk (indikator) dari tahapan pemanfaatan ruang ini adalah adanya rencana pemanfaatan ruang yang mampu mengurangi risiko bencana dan daya dukung lahan terhadap struktur bangunan yang direncanakan. Tolok ukur untuk kriteria ini adalah adanya:

- Program rencana lokasi dan kebijakan pembiayaan manifestasi pusat/ sub pusat pemukiman di kawasan reklamasi.

- Program rencana pemanfaatan lahan bagi lokasi aktifitas pelayanan masyarakat yang penting, fasilitas berbahaya, dan pembangunan hunian khusus, di kawasan reklamasi;

- Program dan kebijakan pembiayaan dalam rangka alokasi fasilitas berbahaya, fasilitas pelayanan penting, hunian khusus di kawasan reklamasi.

- Rencana pemanfaatan lahan di kawasan non budidaya (di laut) untuk bangunan fisik pertahanan pantai, seperti pemecah gelombang (sea wall), tanggul (dike), bukit pasir (sand dunes). Rencana ini akan terintegrasi dengan pemanfaatan lahan pantai, seperti hutan bakau, hamparan karang laut 
dan zona penyangga yang difungsikan sebagai perlindungan pantai kawasan reklamasi.

- Rencana pemanfaatan lahan kawasan reklamasi (mixed use of land) untuk berbagai penggunaan seperti lokasi evakuasi dalam bentuk peningkatan jumlah taman kota, serta kesiapan lahan untuk mendirikan bangunan permukiman, baik bangunan horizontal maupun bangunan vertikal pada kawasan yang direncanakan berpenduduk kepadatan rendah.

- Program rencana peningkatan kualitas infrastruktur seperti pelebaran jalur jalan, peningkatan jumlah ruang publik atau fasilitas penampungan yang aman bila terjadi bencana banjir.

- Adanya program rencana pengendalian penyebaran penduduk melalui distribusi pemusatan yang terpisah (dekonsentrasi) antara permukiman dan industri.

\subsubsection{Tahapan Proses Pengendalian Kawasan Reklamasi}

Sebagai bagian dari penambahan areal perkotaan atau kabupaten dengan luas yang terbatas, kawasan reklamasi bukan tidak memiliki kelemahan. Untuk itu dibutuhkan pengendalian melalui penataan ruangnya.

Petunjuk (indikator) pada tahap pengendalian ruang ini adalah diterapkannya dan berjalannya peraturan yang berkaitan dengan upaya pengurangan risiko bencana di kawasan reklamasi. Acuannya adalah adanya:

- Adanya rujukan pengendalian pembangunan yang disertai dengan aturan pemanfaatan ruang yang lengkap dan akurat.

- Aturan yang mengatur tata massa bangunan secara mendetail seperti tinggi bangunan, garis sempadan bangunan, jarak antar bangunan, luas minimum kavling, bentuk rongga pada bagian dasar rumah (Wikantyoso, 2010).
- Peraturan zonasi pada dasarnya mencakup aturan-aturan yang berkaitan dengan penggunaan lahan dan bangunan (penggunaan utama, penggunaan pelengkap, penggunaan bersyarat, penggunaan dengan pengecualian khusus, penggunaan yang dilarang).

- Intensitas pemanfaatan ruang atau kepadatan pembangunan dan peraturan bangunan yang berlaku.

- Pengendalian program pembangunan melalui kebijakan insentif dan disinsentif, perizinan, pengawasan, dan penertiban.

- Peraturan khusus yang berkaitan dengan perlindungan pantai (pengaturan khusus mengenai batas garis sempadan pantai dan sungai).

- Pengembangan hutan bakau untuk meredam energi gelombang pantai (Pratikto, 2004).

Petunjuk (indikator) lainnya adalah tersusunnya struktur dan pola ruang pada area di luar kawasan rendaman. Tolok ukurnya adalah :

- Terealisasikannya pusat permukiman yang berada di kawasan reklamasi.

- Jaringan jalan sebagai jalur penghubung dengan daratan dan evakuasi yang merupakan jalan utama yang cukup lebar berada pada kawasan reklamasi.

- Terdapat jaringan jalan lokal yang dibangun yang dibangun disekeliling kawasan reklamasi yang berfungsi sebagai jalur inspeksi serta jalan lokal tegak lurus garis pantai yang cukup lebar.

- Seluruh fasilitas pelayanan penting, fasilitas berbahaya, dan bangunan hunian khusus tidak berada dekat dengan kawasan pemukiman.

- Terdapat rencana zona penyangga buatan atau alam yang berfungsi sebagai pelindung terhadap gelombang laut (seawall/ breakwater/ dike/ sand dunes, mangrove/ coral reefs), serta kawasan terbuka dalam bentuk lahan 
rekreasi pantai atau pemeliharaan ikan air payau berbatasan dengan garis pantai).

- Pelarangan pembangunan fisik non perlindungan pantai di kawasan sempadan pantai.

\section{KESIMPULAN}

Reklamasi merupakan jawaban akan tuntutan kebutuhan lahan perkotaan pantai yang dipertimbangkan secara bijaksana mengingat reklamasi juga dapat menjadi sumber masalah seperti perubahan garis pantai. Untuk itu pertimbangan terhadap faktor yang berpengaruh menjadi hal yang sangat penting.

1. Faktor Kesiapan Kawasan Reklamasi merupakan langkah utama sebelum seluruh kegiatan di kawasan tersebut berjalan. Beberapa hal seperti perhitungan terhadap aspek perubahan garis pantai (hidrodinamika pantai), aspek struktur bangunan pantai dan persyaratannya, metoda reklamasi yang digunakan, bahan pengurugan yang dipakai, lokasi pengambilan bahan urugan dan standarnya perlu dipertimbangkan. Spesifikasi teknis reklamasi akan dibutuhkan.

2. Faktor Implementasi Proses Reklamasi yang menyangkut persyaratan perlu dipertimbangkan terutama yang terkait dengan bangunan laut, proses pembebanan sementara, pengurugan dan pemadatan, geotextile, dan vertical drain. Demikian pula penekanan tanah urugan dilakukan sehingga tidak terjadi amblesan dikemudian hari. Pengambilan material urugan ini dilakukan pada kawasan perbukitan yang tidak berpenghuni dengan izin dari pemerintah daerah. Pengambilan material urugan tidak dianjurkan pengambilannya dari pulau kecil di sekitarnya. Pengambilan material pengurugan dari dasar laut dapat diperkenankan dengan pertimbangan adanya perlindungan lingkungan laut.

3. Faktor Paska Reklamasi berkaitan dengan berbagai persyaratan teknis yang dibutuhkan untuk pembangunan struktur fisik bangunan perlindungan gelombang laut.

4. Faktor Pengendalian Dampak Negatif Lingkungan yang merupakan campur tangan manusia melawan alam di kawasan pantai, seperti adanya limpasan air sebagai dampak dari reklamasi yang mengakibatkan banjir di kawasan lain. Hal lain yang dipertimbangkan adalah ketersediaan air bersih dan energi. Tidak semua lokasi di kawasan reklamasi akan diperoleh air bersih mengingat kawasan itu sendiri merupakan areal yang digenangi oleh air asin, sehingga akan membebani ketersediaan air di daratan.

\section{DAFTAR PUSTAKA}

Dooley, J.,1996.'Panduan Pelatihan Analisis Bencana dan Pengelolaan Risiko, Terjemahan oleh Roma Chrysta Manurung, Pusat Studi Lingkungan Hidup ITB, Bandung.

http://www.penataanruang.com/reklamasipantai.html.

https://outsidergianyar.wordpress.com/ pengertian-reklamasi/

http://materiperkapalan.blogspot.com/2014/11/ pengertian-dan-tujuan-reklamasi-untuk. html

http://www.academia.edu/4293653/Reklamasi pantai_dandampaknya_terhadap_ wilayah_pesisir.

https://beritasepuluh.com/2016/04/18/opinipakar-tentang-reklamasi-teluk-jakarta/

http://www.penataanruang.com/reklamasipantai.html. 
Jurnal Sains dan Teknologi Mitigasi Bencana, Vol. 11, No. 1, Tahun 2016

Departemen Pekerjaan Umum, Direktorat Jenderal Penataan Ruang, 2008, Modul Terapan Pedoman Perencanaan Tata Ruang Kawasan Reklamasi Pantai, Jakarta.

Pratikto, W. A., 2004, Mitigasi Bencana Tsunami, Artikel Harian Republika, 31Desember 2004.

Wikantiyoso, R., 2010, Mitigasi Bencana di Perkotaan; Adaptasi atau Antisipasi Perencanaan dan Perancangan Kota?, Potensi Kearifan Lokal dalam Perencanaan dan Perancangan Kota untuk Upaya Mitigasi Bencana, Local Wisdom, Volume:II, Nomor: 1. Halaman: 18 - 29, Januari. 